\title{
PENGEMBANGAN KONSELING DALAM LAYANAN ANTENATAL CARE DENGAN MENGGUNAKAN MULTIMEDIA
}

\section{DEVELOPING OF COUNSELING IN ANTENATAL CARE SERVICES USING MULTIMEDIA}

\author{
Rosida Hi.Saraha \\ Program Studi Diploma III Kebidanan, Politeknik Kesehatan Kementerian Kesehatan Ternate \\ Korespondensi: sidahisaraha@yahoo.co.id
}

\begin{abstract}
Adequate of antenatal care by professional healthcare providers has been proven not only to reduce maternal, fetal and infant morbidity and mortality but also to improve the health status and parenting behavior after the child was born. Health practices have and will continue to improve services by using technology in health care. One of the health service providers is expected to be able to modify the provision of counseling in antenatal services by using multimedia to improve the quality of service that will have an impact on patient satisfaction. The purpose of this study was to determine the level of satisfaction with antenatal care services using multimedia. The design used in this study is a Quasi-experiment with the design of this study is One Group Pre Test Post Test Design. The results, statistically, there are differences in the level of satisfaction with communication in Antenatal Care Services without Using and Using Multimedia with a value of $p<0.003$.
\end{abstract}

Keywords $\quad$ : Counseling, antenatal services, Multimedia

\begin{abstract}
ABSTRAK
Antenatal care yang memadai oleh penyedia layanan kesehatan profesional telah terbukti tidak hanya untuk mengurangi morbiditas dan mortalitas ibu, janin dan bayi tetapi juga untuk meningkatkan status kesehatan dan perilaku pengasuhan ibu setelah anak lahir. Praktik kesehatan telah dan akan terus berlanjut meningkatkan layanan dengan menggunakan teknologi dalam perawatan kesehatan. Pemberi layanan kesehatan salah satunya bidan diharapkan dapat memodifikasi pemberian konseling dalam layanan antenatal dengan menggunakan multimedia untuk meningkatkan kualitas layanan yang akan berdampak pada kepuasan pasien. Tujuan dari penelitian ini untuk mengetahui tingkat kepuasan terhadap layanan antenatal care menggunakan multimedia. Rancangan yang digunakan dalam penelitian ini adalah Quasi eksperimen dengan desain penelitian ini adalah One Group Pre Test Post Test Design. Hasil, secara statistik terdapat perbedaan tingkat kepuasan terhadap komunikasi dalam Layanan Antenatal Care yang Tanpa Menggunakan dan Menggunakan Multimedia dengan nilai $\mathrm{p}<0,003$.
\end{abstract}

\section{Kata Kunci : Konseling, layanan antenatal, Multimedia}




\section{PENDAHULUAN}

Selama dua dekade terakhir, di Amerika Serikat dan Eropa telah diberikan pendapat, harapan dan pengalaman perempuan menggunakan pelayanan kesehatan. Kepuasan konsumen memainkan peran penting dalam kualitas reformasi perawatan. Kepuasan pasien adalah refleksi dari penilaian pasien dari domain yang berbeda, mulai dari perawatan kesehatan, termasuk teknis, interpersonal, dan aspek organisasi. literatur internasional menunjukkan bahwa kepuasan dengan aspek yang berbeda dari perawatan antenatal yang diterima dapat meningkatkan kesehatan, kelangsungan perawatan, kepatuhan terhadap pengobatan, dan hubungan dengan penyedia. Organisasi Kesehatan Dunia (WHO) merekomendasikan monitoring dan evaluasi kepuasan ibu dengan pelayanan kesehatan masyarakat, dalam rangka meningkatkan kualitas dan efisiensi pelayanan kesehatan selama kehamilan (Galle A et all, 2015).

Strategis baru pada monitoring pelayanan kesehatan menegaskan bahwa antenatal care adalah tindakan pencegahan yang efektif, sementara kualitas pelayanan masih menjadi masalah yang memerlukan pemantauan dan evaluasi tambahan Yeoh PL et all, (2015). Kualitas pelayanan dianggap sebagai konsep multidimensional yang telah diberikan arti yang berbeda dalam literatur. Kualitas pelayanan dapat dipahami dalam dua aspek: struktur sumber daya organisasi perawatan dan preferensi pasien (Galle A et all, 2015). Telah dikembagkan pedoman untuk memberikan panduan tentang perawatan yang memadai, jumlah kunjungan dan konten dari perawatan rutin. Selain mengukur jumlah kunjungan, kualitas konten perawatan harus dinilai (Yeoh PL et all, 2015).

Kepuasan pasien telah digunakan sebagai indikator kualitas pelayanan. Kepuasan pasien adalah persepsi subjektif dan dinamis dari sejauh mana kebutuhan perawatan kesehatan diharapkan pasien terpenuhi. Studi yang ada menunjukkan bahwa faktor-faktor seperti waktu tunggu sebelum konsultasi, kontinuitas dalam melihat petugas kesehatan yang sama, komunikasi dengan petugas kesehatan, pengaturan dan lingkungan fisik semua berdampak pada kepuasan perempuan dengan perawatan antenatal. Baru-baru ini ada kesepakatan bahwa kepuasan perempuan dengan perawatan antenatal ditentukan oleh interaksi antara harapan mereka dan karakteristik kesehatan yang mereka terima. Dalam prakteknya, harapan 
dapat merujuk ke perawatan kesehatan yang ideal, perawatan kesehatan diantisipasi, atau perawatan kesehatan yang diinginkan, dan kadang-kadang orang tidak memiliki harapan eksplisit. Kami menggunakan pendekatan kedua dan mendefinisikan harapan sebagai keyakinan wanita hamil tentang isi, jenis dan kualitas perawatan yang ia akan terima. Christaens \& Bracke menunjukkan korelasi positif antara harapan dan kepuasan, dengan pemenuhan harapan menjadi salah satu prediktor terhadap kepuasan (Galle A et all, 2015).

Antenatal care yang memadai oleh penyedia layanan kesehatan profesional telah terbukti tidak hanya untuk mengurangi morbiditas dan kematian ibu, janin dan bayi tetapi juga untuk meningkatkan status kesehatan dan perilaku pengasuhan ibu setelah anak lahir. Ketidakpuasan dapat menjadi faktor utama dalam penggunaan fasilitas layanan antenatal, kepuasan dapat meningkatkan frekuensi kunjungan dan hubungan baik dengan penyedia layanan (Galle A et all, 2015).

Penelitian menunjukkan bahwa berbagai upaya yang dilakukan untuk meningkatkan transfer informasi penting selama konsultasi antenatal: wanita tampaknya puas dengan aspek teknis pelayanan antenatal tetapi juga melaporkan kurangnya komunikasi oleh para tenaga kesehatan terutama membahas masalahmasalah kesehatan. Sebuah studi baru-baru ini telah menunjukkan bahwa wanita hamil yang mendapatkan pelayanan antenatal dari bidan mempunyai masalah dalam pemberian konseling lebih sedikit dibandingkan dengan tenaga kesehatan lainnya. Hal ini menunjukkan bahwa tugas bidan dalam memberikan pelayanan antenatal dapat menurunkan kehamilan dengan berisiko tinggi dan menciptakan komunikasi yang lebih baik selama memberikan layanan pemeriksaan kehamilan (Galle A et all, 2015).

Bidan adalah penyedia layanan kesehatan utama selama kehamilan. Pelayanan kebidanan oleh bidan adalah model yang telah menunjukkan efektivitas, kepuasan, dan biaya yang lebih rendah dalam beberapa penelitian. Dalam rangka meningkatkan pelayanan antenatal, penyedia harus lebih fokus pada fitur pengaturan perawatan antenatal (seperti di akses, waktu dan ketersediaan layanan tambahan) bukan hanya berkonsentrasi terutama pada kemampuan teknis (Galle A et all, 2015).

Pendidikan antenatal dianggap penting untuk mempengaruhi perilaku perempuan 
dan hasil kelahiran. Kurangnya informasi yang diberikan kepada wanita sering merupakan faktor penting karena tidak puas dengan pelayanan antenatal. Hal ini penting mengingat bahwa sumber informasi utama yang digunakan oleh wanita selama kehamilan untuk memenuhi kebutuhan informasi mereka tentang kehamilan, kelahiran dan masa postpartum. Sebuah studi menemukan bahwa $70 \%$ dari wanita hamil melakukan "diskusi dengan bidan" sebagai sumber informasi, kurang dari setengah dari perempuan menggunakan internet untuk mengakses informasi, dan hanya 2,4\% informasi grup (Yeoh PL, 2015).

Praktik kesehatan telah dan akan terus berlanjut meningkatkan layanan dengan menggunakan teknologi informatika dan perawatan kesehatan. Salah satu upaya peningkatan teknologi yaitu dengan penggunaan termometer sederhana ke termometer digital, monitor hemodinamik dan sistem informasi manajemen klinis terkomputerisasi sepenuhnya. Informatika dan teknologi perawatan kesehatan telah berevolusi untuk meminimalisir tingkat kerumitan yang pernah dialami sebelumnya oleh penyedia layanan kesehatan. Pengenalan teknologi ke dalam pelayanan kesehatan berarti bahwa tidak ada petugas kesehatan yang tidak menggunakan teknologi, setidaknya satu bentuk teknologi dalam pemberian layanan kesehatan. Jadi penting bagi petugas kesehatan untuk meningkatkan pengetahuan dan ketrampilan mereka tentang teknologi, yang memiliki efek mendalam pada penerapan teknologi dan kemampuannya. Semakin banyak penggunaan teknologi dalam perawatan kesehatan berarti perawat dan penyedia layanan kesehatan lainnya memerlukan lebih banyak informasi tentang teknologi, dan diyakini bahwa pemahaman teknologi yang lebih baik akan berdampak pada kualitas, keamanan dan biaya perawatan (Abbaszadeh A, 2011).

Pemberi layanan kesehatan salah satunya bidan diharapkan dapat memodifikasi pemberian layanan antenatal dengan menggunakan komputer untuk meningkatkan kualitas layanan yang akan berdampak pada kepuasan pasien. Kita dapat menyimpulkan bahwa perempuan rentan kurang puas terhadap pelayanan antenatal care yang mereka terima dan banyak faktor lain selain pengalaman mereka sebagai pasien, seperti jaringan sosial, asuransi, dan lingkungan. Oleh karena itu meningkatkan kepuasan pada wanita hamil adalah tujuan 
dari pelayanan kebidanan berbasis kebtutuhan individu. Bidan Praktik Mandiri (BPM) dan klinik adalah tempat layanan kebidanan dasar (antenatal, intranatal, postnatal, bayi baru lahir, KB dan kesehatan reproduksi) yang dikelola secara mandiri atau kelompok. BPM di Kota Ternate berjumlah 9 dan 1 klinik kebidanan. Dari hasil kunjungan terlihat bahwa pemberian konseling pada ibu hamil menggunakan alat peraga berupa lembar balik, liflet dan bahkan tanpa alat peraga. Hal ini ditunjang dengan hasil wawancara $10 \mathrm{ibu}$ hamil tentang kepuasan terhadap pelayanan terutama pada waktu konseling, bahwa 6 dari $10 \mathrm{ibu}$ hamil mengatakan tidak puas karena waktu yang terlalu singkat, tidak menyampaikan hasil pemeriksaan secara rinci, dan tidak menggunakan alat bantu. Latar belakang pendidikan bidan yang mempunyai BPM di Kota Ternate adalah DIII Kebidanan, D-IV Kebidanan dan Magister Manajemen Kesehatan dan Magister Kesehatan Reproduksi, sehingga sudah terbiasa dalam mengoprasikan komputer, namun belum dimanfaatkan dalam memberikan layanan konseling antenatal care. Jadi penelitian ini berusaha untuk menggunakan konsep teknologi (multimedia) dalam memberikan layanan konseling antenatal care.

\section{METODE}

Rancangan penelitian yang digunakan dalam penelitian ini adalah Quasi eksperimen. Desain penelitian ini adalah One Group Pre Test Post Test Design. Populasi dalam penelitian ini adalah seluruh ibu hamil yang melakukan pemeriksaan kehamilan lebih dari satu kali di Bidan Praktik Mandiri (BPM) yang berada di Kota Ternate selatan, tengah dan utara sebanyak 5 BPM. Adapun jumlah populasi diambil dari jumlah kunjungan antenatal dalam satu waktu (satu hari) yaitu sebanyak 20 orang. Sampel pada penelitian ini adalah total sampling berjumlah $20 \mathrm{ibu}$ hamil yang melakukan pemeriksaan lebih dari satu kali pada satu waktu (satu hari). Analisis yang digunakan adalah analisis univaribel dan bivariabel (statistik non parametrik dengan uji t tes).

\section{HASIL DAN PEMBAHASAN}

Karakteristik responden digunakan untuk mengetahui keragaman dari responden berdasarkan usia, pendidikan dan pekerjaan. Sesuai dengan hasil penelitian, karakteristik responden dapat dilihat melalui tabel berikut: 
Tabel 1. Karakteristik responden berdasarkan Usia

\begin{tabular}{|l|c|c|}
\hline \multicolumn{1}{|c|}{ UMUR } & JUMLAH & PRESENTASE \\
\hline$\leq 20$ tahun & 7 & 35 \\
$21-30$ tahun & 9 & 45 \\
$31-40$ tahun & 4 & 20 \\
$41-50$ tahun & 0 & 0 \\
\hline 51 tahun & 0 & 0 \\
\hline TOTAL & 20 & 100 \\
\hline
\end{tabular}

Berdasarkan karakteristik umur 9 orang dengan presentase sebesar $45 \%$, dan responden pada tabel 1 tersebut, responden yang berumur antara 31 - 40 menunjukkan bahwa responden yang tahunse banyak 4 orang dengan presentase berumur $\leq 20$ tahun sebanyak 7 orang sebesar 20\%. Semakin dewasa usia dengan presenatase sebesar 35\%, responden seseorang maka pengalaman yang diperoleh yang berumur antara 21 - 30 tahun sebanyak juga lebih banyak.

Tabel 2. Karakteristik responden berdasarkan Pendidikan

\begin{tabular}{|c|c|c|}
\hline Pendidikan & JUMLAH & PRESENTASE \% \\
\hline SD/sederajat & & 0 \\
\hline SLTP/sederajat & 5 & 25 \\
\hline STLA/sederajat & 13 & 65 \\
\hline S1 & 2 & 10 \\
\hline TOTAL & 20 & 100 \\
\hline
\end{tabular}

dengan tingkat pendidikan SLTP dan S1

Berdasarkan karakteristik pendidikan responden pada tabel 2, menunjukkan bahwa responden dengan tingkat pendidikan terakhir adalah SLTA/sederajat lebih tinggi $65 \%$ atau sebanyak 13 orang dibandingakan berjumlh 7 orang (35\%). Tingkat pendidikan dapat mempengaruhi tingkat pemahaman responden dalam mengisi kuisioner, yang pada khirnya dapat mempengaruhi hasil penelitian. 
Tabel 3. Karakteristik responden berdasarkan Pekerjaan

\begin{tabular}{|c|c|c|}
\hline Pekerjaan & JUMLAH & PRESENTASE \% \\
\hline PNS/TNI/POLRI & & 0 \\
\hline Wiraswasta & 2 & 10 \\
\hline Pelajar/Maahasiswa & 2 & 10 \\
\hline Ibu Rumah Tangga & 16 & 80 \\
\hline TOTAL & 20 & 100 \\
\hline
\end{tabular}

Karakteristik responden berdasarkan dengan pekerjaan wiraswasta dan pelajar / pekerjaan pada tabel 2 diatas, menunjukkan mahasiswa yaitu sebesar 4 orang (20\%).

bahwa jenis pekerjaan ibu rumah tangga Tingkat kepuasan terhadap komunikasi lebih besar dengan jumlah 16 orang atau dalam layanan antenatal care tanpa $80 \%$ dibandingkan dengan responden menggunakan multimedi dan menggunakan multimedia.

Tabel 4 Perbandingan Tingkat Kepuasan Konseling pada Layanan Antenatal Care Tanpa Menggunakan Multimedia dan Menggunakan Multimedia

\begin{tabular}{lllll}
\hline \multirow{2}{*}{ Konseling } & \multicolumn{2}{l}{ Tanpa Menggunakan (Pre Test) } & \multicolumn{2}{c}{ Menggunakan (Post Test) } \\
\cline { 2 - 4 } & Frekuensi (f) & Persentase (\%) & Frekuensi (f) & Persentase (\%)
\end{tabular}

\begin{tabular}{lcccc}
\hline Puas & 10 & 50 & 12 & 60 \\
Tidak Puas & 10 & 50 & 8 & 40 \\
\hline Jumlah & 20 & 100 & 20 & 100 \\
\hline
\end{tabular}

multimedia (Post Test) yang puas sebanyak

Tabel 4 menggambarkan bahwa $60 \%$ dan tidak puas sebanyak $40 \%$.

kelompok tanpa menggunakan multimedia Perbedaan Tingkat Kepuasan Terhadap (Pre Test) yang puas dan tidak puas Komunikasi dalam Layanan Antenatal Care memiliki persentase yang sama yaitu 50\%, yang Menggunakan dan Tidak sedangkan kelompok menggunakan

Menggunakan Multimedia

Tabel 5 Perbedaan Tingkat Kepuasan Terhadap Komunikasi dalam Layanan Antenatal Care yang Tanpa Menggunakan dan Menggunakan Multimedia

\begin{tabular}{lcc}
\hline \multirow{2}{*}{ Konseling } & \multicolumn{2}{c}{ Kelompok } \\
\cline { 2 - 3 } Mean (X) & Pre Test & Post Test \\
\hline Standar Deviasi (SD) & 52,60 & 56,60 \\
Nilai p* & 5,325 & 5,576 \\
\hline Keterangan: *Uji T berpasangan & \multicolumn{2}{c}{0,003} \\
\hline
\end{tabular}


Hasil penelitian sebagaimana tercantum dalam Tabel 5 ditemukan perbedaan yang bermakna secara statistik dengan rerata skor komunikasi layanan antenatal care yang menggunakan dan tidak menggunakan multimedia $(\mathrm{p}<0,05)$. Hasil penelitian ini sejalan dengan penelitian yang dilakukan sebelumnya oleh Sisca Solang dkk tahun 2012 yang menyatakan bahwa terdapat perbedaan yang bermakna antara layanan komunikasi menggunakan multimedia dengan yang tidak menggunakan multimedia $(\mathrm{p}<0,05)$.

Hasil penelitian Sisca Solang dkk tahun 2012, bahwa dari hasil penelitian responden sebagian besar merasa puas dengan pelayanan yang diberikan dengan kategori Puas 36 responden $(59,1 \%)$ dengan jumlah ferkuensi kunjungan kurang sebanyak 39 responden $(63,9 \%)$. Dan kategori Tidak Puas sebanyak 25 responden (41\%) dengan Jumlah frekuensi baik sebanyak 22 responden (36,1\%). Dari hasil uji SPSS nilai $\mathrm{P}$ (signifikan) $=0,000<\alpha=0,05$ berarti secara statistik terdapat hubungan antara kepuasan pelayanan dengan ferkuensi kunjungan Antenatal Care. Dalam penelitian ini di ketahui bahwa kualitas pelayanan yang terbanyak adalah kualitas pelayanan yang baik yaitu $38(62,2 \%)$. Kualitas pelayanan adalah suatu tingkat keunggulan dari pelayanan yang diharapkan ibu hamil dalam pelayanan Antenatal Care tetapi pada penelitian ini frekuensi kunjungan yang sebagian besar $<4$ kali kunjungan. Menurut Windra (2010) kualitas pelayanan yang baik mempengaruhi proses kesembuhan atau mengurangi keluhan yang dirasakan oleh ibu hamil. Jika ibu hamil merasa puas dengan jasa pelayanan yang digunakan maka ibu hamil akan senantiasa untuk melanjutkan menggunakan jasa layanan tersebut. Kurangnya kualitas pelayanan yang diberikan oleh petugas kesehatan seperti ketepatan waktu pelayanan yang meliputi waktu tunggu dan waktu proses, kemudahan mendapatkan pelayanan misalnya banyaknya petugas yang melayani, tidak mencuci tangan sebelum dan sesudah melakukan pelayanan dan petugas juga sering lupa untuk bertanya tentang keluhan yang dirasakan oleh ibu hamil pada saat pemeriksaan. Dalam penelitian terdapat $35(57,4 \%)$ yang menyatakan fasilitas yang lengkap, akan tetapi jumlah frekuensi kunjungan yang $<4$ juga sangat besar jumlahnya. Kurangnya fasilitas yang tersedia di tempat pelayanan juga mempengaruhi motifasi ibu hamil untuk datang berkunjung memeriksakan kehamilannya seperti kurangnya fasilitas tempat duduk diruang tunggu sehingga tingkat frekuensi responden kurang dalam melakukan kunjungan ulang dan mempengaruhi tingkat kepuasan ibu hamil. Berdasarkan hasil uji statistik dengan 
menggunakan SPSS 16 for windows, dimana nilai $\mathrm{p}=0,00<\alpha=0,05$ dengan demikian penelitian tersebut menunjukkan bahwa ada Hubungan antara Kepuasan pelayanan dengan Kunjungan Antenatal Care. Berdasarkan hasil analisa sebagian besar responden merasa Puas dengan pelayanan yang diberikan, namun bila dilihat dari frekuensi kunjungan sebagian besar responden kurang melakukan kunjungan. Dari 61 responden yang menjawab kuesioner sejumlah 30 pertanyaan dapat diketahui $36(59 \%)$ ibu hamil yang menyatakan puas dan 25 (41\%) menyatakan tidak Puas, ini berarti penampilan tenaga kesehatan dalam memberikan pelayanan memuaskan atau sesuai harapan ibu hamil saat datang berkunjung dipuskesmas. Perasaan sangat puas ini dipengaruhi oleh sikap staf tenaga kesehatan saat bertemu misalnya tersenyum dan menyapa dengan ramah, ibu hamil akan merasa nyaman dengan keramahan yang diberikan. Hal tersebut juga perlu ditunjang dengan kualitas pelayanan yang baik, apa saja yang dilakukan petugas kesehatan kepada ibu hamil berkaitan dengan proses kesembuhan atau mengurangi keluhan yang dirasakan oleh ibu hamil. Penelitian ini sejalan dengan penelitian yang dilakukan oleh Windra ( 2010 ) kesimpulannya ada hubungan antara kepuasan ibu hamil terhadap pelayanan bidan dengan frekuensi kunjungan Antenatal Care. Berdasarkan hasil analisa bahwa sebagian besar responden melakukan kunjungan pemeriksaan kehamilan dengan frekuensi kunjungan yang kurang yaitu 39 orang $(63,9 \%)$, dan frekuensi kunjungan yang baik yaitu 22 orang $(36,1 \%)$. Hal ini di akibatkan karena kurang pedulinya ibu hamil tentang pentingnya berpartisipasi dalam melakukan kunjungan pemeriksaan kehamilan (Sisca dkk, 2012).

Hasil penelitian ini menunjukkan bahwa pemberian konseling tanpa menggunakan multimedia (lembar balik, leaflet dan poster) memperoleh tingkat kepuasan sebesar 50\%, hal ini sejalan dengan hasil penelitian Niken Purbowanti tahun 2016 tentang pengaruh konseling terhadap lembar balik dan leaflet terhadap kepatuhan ibu hamil mengkonsumsi tablet besi, Hasil penelitian menunjukkan tidak ada perbedaan karakteristik ibu hamil (umur, pendidikan, dukungan suami, pekerjaan, pendapatan) antara kelompok perlakuan dan kelompok kontrol. Ada perbedaan bermakna skor pengetahuan setelah perlakuan antara kedua kelompok $(\mathrm{p}=0,001)$. Ada perbedaan bermakna skor sikap setelah perlakuan antara kedua kelompok $(p=0,001)$. Kepatuhan konsumsi tablet besi lebih tinggi pada kelompok 
perlakuan $(89,7 \%)$ daripada kelompok kontrol $(25,9 \%)$. Ada perbedaan bermakna kepatuhan mengkonsumsi tablet besi antara kelompok perlakuan dan kelompok kontrol $(\mathrm{p}=0,001)$. Suplementasi tablet besi tidak hanya cukup melakukan pengadaan dan distribusi kepada sasaran, namun harus disertai kegiatan yang menumbuhkan kesadaran dan kebutuhan akan tablet besi. Hal ini dapat dicapai melalui pelaksanaan Komunikasi Informasi Edukasi (KIE) yang berkualitas. Setiap pendekatan memerlukan media KIE yang sesuai dengan metode yang digunakan, seperti konseling menggunakan media alat bantu (Depkes RI, 2001). Konseling tentang anemia dan pemberian tablet besi, diharapkan meningkatkan kepatuhan ibu hamil mengkonsumsi tablet besi. Hasil penelitian ini sama dengan yang dilakukan oleh Susetyowati, ada perbedaan konsumsi tablet besi antara kelompok perlakuan yang diberi penyuluhan dengan kelompok kontrol (Susetyowati, 2010). Program penanggulangan anemia gizi besi (AGB) pada ibu hamil sangat bervariasi, tidak hanya cukup pengadaan dan distribusi suplementasi tablet besi, namun harus disertai pemberian informasi yang bersifat spesifik kepada setiap segmen sasaran ibu hamil di masyarakat. Untuk mengantisipasi masalah timbulnya pengetahuan, sikap dan perilaku, maka perlu dilaksanakan kegiatan konseling yang berkualitas. Untuk melakukan kegiatan konseling terhadap sasaran ibu hamil, membutuhkan waktu dan seni tersendiri untuk dapat meyakinkan sehingga mau menerima informasi yang disampaikan oleh tenaga kesehatan. Tahapan tersebut melalui proses panjang dari hanya sekedar tahu sampai mau menerima gagasan baru, yaitu teratur mengkonsumsi tablet besi. Kegiatan konseling ini perlu diulang, sehingga ibu hamil mau menerima isi pesan dan mengadopsi gagasan baru (Niken Purbowanti, 2016).

Menurut Hardi Prasetiawan pada prosiding seminar bimbingan dan konseling tahu 2017, bahwa Pemanfaatan media dalam layanan Bimbingan dan Konseling yang relevan dalam kelas dapat mengoptimalkan proses layanan Bimbingan dan Konseling. Bagi Guru BK/Konselor, media membantu mengkonkritkan konsep atau gagasan dan membantu memotivasi peserta didik/konseli dapat belajar denganaktif. Bagi peserta didik/konseli, media dapat menjadi jembatan untuk berpikir kritis dan berbuat, dengan demikian media dapat membantu tugas Guru BK/Konselor dan peserta didik/konseli mencapai kompetensi dasar yang ditentukan. Agar media dapat dimanfaatkan dengan baik dalam layanan Bimbingan dan Konseling, Guru BK/Konselor perlu mengetahui kebutuhan layanan Bimbingan 
dan Konseling dan permasalahanpermasalahanyang dihadapi peserta didik/konseli tentang materi yang akan disampaikan. Maka dalam ini, media perlu dikembangkan berdasarkan relevansi, kompetensi dasar, materi dan karakteristik peserta didik/konseli. Guru BK/Konselor dapat berperan sebagai kreator yaitu menciptakan dan memanfaatkan media yang tepat, efisen, dan menyenangkan bagi peserta didik/konseli (Prasetiawan Hardi, 2017).

Era Teknologi Informasi dalam hal ini tertujupada penggunaan komputer yang mana telah merambah ke segala bidang kehidupan, termasuk dalam dunia pendidikan. Menurut Triyanto (2006) Komputer memiliki program-program aplikasi praktis yang dapat dimanfaatkan dan dikembangkan untuk pencapaian tujuan pendidikan. Beberapa orientasi penggunaan komputer dalam dunia pendidikan adalah bagaimana komputer dapat membantu seseorang untuk belajar, mengajar, dan membantu orang lain dalam mengelola pendidikan secara umum, begitu juga dalam pengembangan bahan-bahan atau materipembelajaran, sebagai alternatif sumber belajar, komputer digunakan untuk mentransfer materi-materi kepada peserta didik atau dalam konteks ini biasa disebut dengan bahan pembelajaran berbasis komputer (Prasetiawan Hardi, 2017).

Berkembangnya ilmu pengetahuan dan teknologi merupakan perwujudan terjadinya perubahan kearah positif budaya yang dimiliki oleh manusia. Hal ini didasari pada sebuah keyakinan bahwa setiap hasil dari daya yang dimiliki manusia baik cipta, rasa, karsa dan karya yang dikatakan sebagai sebuah budaya dalam wujud teknologi akan meningkatkan produktifitas kerja manusia. Dikatakan demikian karena teknologi tercipta sedianya akan mempermudah serta meningkatkan efektifitas kerja manusia, sehingga manusia menjadi lebih produktif dalam bekerja. Teknologi juga dapat dikatakan sebagai hasil budaya manusia karena merupakan hasil dari gagasan manusia yang akhirnya melahirkan sebuah karya dan dapat menunjang kehidupan manusia. Salah satu bidang kehidupan manusia yang saat ini sedang giat dalam menempatkan teknologi sebagai bagian penting dari proses dan program kerjanya adalah bidang pendidikan. Pendidikan menjadi salah satu bidang yang mencoba meningkatkan peranan teknologi sebagai salah satu penunjang proses peningkatan efektifitas hasil kerja melalui optimalisasi serapan peserta didik terhadap materi pembelajaran dan pendidikan. BerdasarkanIfdil (2011) Salah satunya 
diwujudkan dengan pemanfaatan mediamedia pembelajaran berbasis komputer yang diharapkan dapat menarik minat dan memotivasi peserta didik dalam pembelajaran. Seperti dengan mulai diterapkannnya pembelajaran berbasis multimedia, e-learning serta pemanfaatan beberapa aplikasi komputer dalam pembelajaran (Prasetiawan Hardi, 2017).

Disis lain, Strategis baru pada monitoring pelayanan kesehatan menegaskan bahwa antenatal care adalah tindakan pencegahan yang efektif, sementara kualitas pelayanan masih menjadi masalah yang memerlukan pemantauan dan evaluasi tambahan Yeoh PL et all, (2015). Kualitas pelayanan dianggap sebagai konsep multidimensional yang telah diberikan arti yang berbeda dalam literatur. Kualitas pelayanan dapat dipahami dalam dua aspek: struktur sumber daya organisasi perawatan dan preferensi pasien (Galle A et all, 2015). Telah dikembagkan pedoman untuk memberikan panduan tentang perawatan yang memadai, jumlah kunjungan dan konten dari perawatan rutin. Selain mengukur jumlah kunjungan, kualitas konten perawatan harus dinilai (Yeoh PL et all, 2015).

Kepuasan pasien telah digunakan sebagai indikator kualitas pelayanan. Kepuasan pasien adalah persepsi subjektif dan dinamis dari sejauh mana kebutuhan perawatan kesehatan diharapkan pasien terpenuhi. Studi yang ada menunjukkan bahwa faktor-faktor seperti waktu tunggu sebelum konsultasi, kontinuitas dalam melihat petugas kesehatan yang sama, komunikasi dengan petugas kesehatan, pengaturan dan lingkungan fisik semua berdampak pada kepuasan perempuan dengan perawatan antenatal. Baru-baru ini ada kesepakatan bahwa kepuasan perempuan dengan perawatan antenatal ditentukan oleh interaksi antara harapan mereka dan karakteristik kesehatan yang mereka terima. Dalam prakteknya, harapan dapat merujuk ke perawatan kesehatan yang ideal, perawatan kesehatan diantisipasi, atau perawatan kesehatan yang diinginkan, dan kadang-kadang orang tidak memiliki harapan eksplisit. Kami menggunakan pendekatan kedua dan mendefinisikan harapan sebagai keyakinan wanita hamil tentang isi, jenis dan kualitas perawatan yang ia akan terima. Christaens \& Bracke menunjukkan korelasi positif antara harapan dan kepuasan, dengan pemenuhan harapan menjadi salah satu prediktor terhadap kepuasan (Galle A et all, 2015).

Antenatal care yang memadai oleh penyedia layanan kesehatan profesional telah terbukti tidak hanya untuk mengurangi morbiditas dan kematian ibu, janin dan bayi tetapi juga untuk meningkatkan status kesehatan dan perilaku pengasuhan ibu 
setelah anak lahir. Ketidakpuasan dapat menjadi faktor utama dalam penggunaan fasilitas layanan antenatal, kepuasan dapat meningkatkan frekuensi kunjungan dan hubungan baik dengan penyedia layanan (Galle A et all, 2015).

Penelitian menunjukkan bahwa berbagai upaya yang dilakukan untuk meningkatkan transfer informasi penting selama konsultasi antenatal: wanita tampaknya puas dengan aspek teknis pelayanan antenatal tetapi juga melaporkan kurangnya komunikasi oleh para tenaga kesehatan terutama membahas masalahmasalah kesehatan. Sebuah studi baru-baru ini telah menunjukkan bahwa wanita hamil yang mendapatkan pelayanan antenatal dari bidan mempunyai masalah dalam pemberian konseling lebih sedikit dibandingkan dengan tenaga kesehatan lainnya. Hal ini menunjukkan bahwa tugas bidan dalam memberikan pelayanan antenatal dapat menurunkan kehamilan dengan berisiko tinggi dan menciptakan komunikasi yang lebih baik selama memberikan layanan pemeriksaan kehamilan (Galle A et all, 2015).

Hasil penelitian sebagaimana tercantum dalam Tabel 4.3 ditemukan perbedaan yang bermakna secara statistik dengan rerata skor komunikasi layanan antenatal care yang menggunakan dan tidak menggunakan multimedia $(\mathrm{p}<0,05)$, hasil penelitian ini menunjukkan bahwa terdapat perbedaan kepuasan konseling dalam layanan antenatal care dengan menggunakan multimedia dan tanpa menggunakan multimedia. Hasil penelitian ini berbeda dengan hasil penelitian yang dilakukan oleh Faqihani Ganiajr tahun 2012 tentang perbedaan pemanfaatan multimedia flash dan ceramah sebagai media pendidikan kesehatan reproduksi remaja bagi remaja awal di SMP Negeri 3 Turi Kabupaten Sleman, dengan tujuan peneltian Tujuan penelitian merancang dan menganalisis media pendidikan kesehatan reproduksi remaja pada remaja awal di SMP Negeri 3 Turi untuk meningkatkan pengetahuan mengenai kesehatan reproduksi remaja dengan menggunakan multimedia flash. Hasil penelitian menunjukkan Hasil penelitian menunjukkan bahwa kelompok dengan metode multimedia flash $(\mathrm{pvalue}=0,146 ; \mathrm{t}$ $=-1,547)$ mempunyai pvalue $>0,05$. Hal ini berarti secara statistik tidak terdapat perbedaan sebelum dan sesudah perlakuan dengan metode multimedia flash. Hasil uji t berpasangan kelompok metode ceramah (pvalue $=0,0001 ; \mathrm{t}=-3,369)$ menunjukkan pvalue $<0,05$ sehingga secara statistik terdapat perbedaan pengetahuan antara sebelum dan sesudah perlakuan Saran untuk sekolah agar membentuk 
adanya peer conselor (kelompok sebaya) untuk menyebarkan informasi mengenai kesehatan, terutama kesehatan reproduksi. Badan Koordinasi Keluarga Berencana Nasional hendaknya mengaktifkan kegiatan Bina Keluarga Remaja (BKR) yang sudah dilaksanakan di dusun masing - masing. Multimedia flash pendidikan reproduksi remaja dibuat dalam bentuk instructional games (permainan dalam pembelajaran). Pemainan ini merupakan salah satu bentuk dari simulasi dalam pelatihan. Aplikasi ini dapat digunakan pada komputer yang didukung dengan flash player. Penambahan perangkat keras berupa sound system berguna untuk mendengarkan penjelasan yang terdapat pada video. Penggunaan satu unit komputer untuk lebih dari satu orang responden dinilai membuat efek dari perlakuan menjadi kurang optimal. Responden terpaksa harus saling tunggu karena kemampuan untuk memahami materi tiap responden berbeda. Selain itu, pada beberapa kelompok terdapat responden yang pasif dalam mengikuti kegiatan. Hal ini terjadi karena mouse sebagai alat navigasi digunakan hanya oleh salah satu orang di kelompok tersebut sehingga tidak memiliki kesempatan untuk menggunakan aplikasi secara bebas. Instructional games adalah permainan dengan interaksi yang spesifik berupa komunikasi interaktif antara peserta didik dan materi pembelajaran. Kontrol terhadap materi pembelajaran adalah fitur penting dari permainan ini. Sebuah permainan instruksional hanya akan efektif jika dirancang untuk memenuhi tujuan instruksional yang spesifik dan digunakan seperti yang dimaksudkan. Metode ceramah merupakan metode yang umum digunakan pada promosi kesehatan, pemberian materi dilakukan secara lisan dengan memanfaatkan media power point. Responden pada kelompok ini memberi umpan balik yang baik dalam penelitian ini. Responden memberikan beberapa pertanyaan saat pemberi materi memberi kesempatan. Pemberi materi dinilai dapat mencairkan suasana karena setiap responden terlihat bosan akan dilakukan ice breaking. Pada beberapa bagian materi, pemberi materi memberikan contoh untuk memperjelas materi yang disampaikan. Power point yang menjadi media penyampaian membantu dalam pemberian contoh ilustrasi pada materi pengenalan organ. Oleh karena itu, penyampaian materi lebih optimal. Salah satu kekurangan dari metode ceramah adalah tidak ada partisipasi dari pihak yang diberi materi (komunikasi searah). Namun, hal ini dikurangi dengan adanya tanya jawab antara responden dengan pemberi materi, sehingga responden dapat memberikan umpan balik. Penggabungan penyampaian materi secara 
lisan dengan power point tersebut menambah efektivitas penyampaian materi. Hal ini sejalan dengan penelitian Nisma menunjukkan hasil yang signifikan pada peningkatan pengetahuan responden pada kesehatan reproduksi dengan menggabungkan metode ceramah dengan pendukung berupa power point, tanya jawab, dan pemberian modul (F Ganiajri, 2012). Namun pada penelitian ini, metode konseling dengan tanpa menggunakan multi media yaitu lembar balik, leaflet, poster dan bahkan hanya menggunakan ceramah dengan waktu yang singkat sehingga komunikasi terjadi hanya kamunikasi satu arah.

Multimedia Flash yang digunakan untuk konseling dalam layanan antenatal care yaitu aplikasi sofware dengan nama Micron Medical Multimedia (M3). Aplikasi tersebut dapat digunakan dalam komputer yang didukung dengan flash player dan untuk memaksimalkan penggunaan dapat dilengkapi dengan hardware sound system. Aplikasi ini terdiri dari beberapa menu utama yang terdiri dari kehamilan, persalinan, nifas, neonatus, kegawatdaruratan maternal neonatal, komunitas, Keluarga Berencana, Kebutuhn Dasar Kebidanan, dan Kuis interaktif.

Konseling dengan menggunakan multimedia, tidak hanya sekedar memberikan pengetahuan kepada ibu hamil, tetapi memberikan gambaran secara nyata tentang permasalahan yang dialami dengan memperlihatkan vidio serta mendapatkan penjelasan baik multimedia maupun dari bidan. Menurut McCormick multimedia secara umum merupakan kombinasi tiga elemen yaitu suara, gambar dan teks. Sedangkan menurut Robin dan Linda, multimedia merupakan alat yang dapat menciptakan presentasi yang dinamis dan interaktif yang mengkombinasikan teks, grafik, animasi, audio dan gambar video.

\section{SIMPULAN}

Berdasarkan hasil penelitian maka dapat diambil kesimpulan sebagai berikut :

1. Responden dengan usia $\leq 20$ tahun sebanyak 7 orang dengan tingkat pendidikan SLTA/sederajat lebih tinggi $65 \%$ atau sebanyak 13 orang serta $80 \%$ adalah ibu rumah tangga.

2. Tingkat Kepuasan Konseling pada Layanan Antenatal Care Tanpa Menggunakan Multimedia dan Menggunakan Multimedia menunjukkan hasil kelompok tanpa menggunakan multimedia (Pre Test) yang puas dan tidak puas memiliki persentase yang sama yaitu 50\%, sedangkan kelompok menggunakan multimedia (Post Test) yang puas 
sebanyak $60 \%$ dan tidak puas sebanyak $40 \%$.

3. Perbedaan Tingkat Kepuasan Terhadap Komunikasi dalam Layanan Antenatal Care yang Tanpa Menggunakan dan Menggunakan Multimedia secara statistik bermakna dengan rerata skor komunikasi layanan antenatal care yang menggunakan dan tidak menggunakan multimedia $\mathrm{p}<0,003$.

4. Konseling dengan menggunakan multimedia, tidak hanya sekedar memberikan pengetahuan kepada ibu hamil, tetapi memberikan gambaran secara nyata tentang permasalahan yang dialami dengan memperlihatkan vidio serta mendapatkan penjelasan baik multimedia maupun dari bidan

\section{UCAPAN TERIMA KASIH}

Program Studi Diploma III Kebidanan Politeknik Kesehatan Kementerian Kesehatan Ternate

\section{DAFTAR RUJUKAN}

Galle A, Van Parys A, Roelens K, Keygnaert (2015). Expectations and satisfaction with antenatal care among pregnant women with a focus on vulnerable groups: a descriptive study in ghent. BMC Women's Health.

Yeoh PL, Hornetz K, Ahmad Shauki NI, Dahlui M (2015). Assessing the extent of adherence to the recommended antenatal care content in Malaysia: Room for improvement. PloS One.

Yeoh PL, Hornetz K, Dahlui M (2015), Antenatal care unilisation and content between Low Risk and High Risk pregnant women. PloS One.
Abbaszadeh Abbas, Sabeghi Hakimeh, Borhani Fariba, Heydari A (2011). A comparative study on effect of e-learning and instructor methods on nurses documentation competency. Iran $\mathbf{J}$ Nurs Midwifery.

Ann-Beth Moller, Max Petzold, Chou D, Say Lale (2017). Early antenatal care visit : a systematic analysis of regional and global levels and trends of coverage from 1990 to 2013. Langet global health.

Peraturan Meteri Keshetan RI Nomor 97 Tahun 2014, Pelayanan kesehatan masa sebelum hamil, masa hamil, persalinan, dan masa sesudah melahirkan, penyelenggaraan pelayanan kontrasepsi, serta pelayanan kesehatan seksual.

Kementerian Kesehatan RI, tahun 2010. Pedoman pelayanan antenata terpadu. Direktur Jendra bina kesehatan masyarakat.

Prasetiawan Hardi, 2017. Optimalisasi multimedia dalam bimbingan dan konseling. Prosiding seminar bimbingan dan konseling.

Pangestu Achmad Y (2013), Gambaran kepuasan pasien padapelayanan rawat jalan di RSU Kota Tengerang Selatan.

Creswell JW (2010). Research design: Pendekatan kualitatif, kuantitatif, dan mixed-3/e.

F Ganiajri (2012), Perbedaan pemanfaatan multimedia flash dan ceramah sebagai media pendidikan kesehatan reproduksi remaja bagi remaja awal di SMP Negeri 3 Turi kabupaten Sleman. http://ejournals1.undip.ac.id/index.php/jkm , Volume 1, Nomor 2, Tahun 2012, Halaman 154 - 162

Niken Purbowati (2016), Pengaruh konseling menggunakan lembar balik dan leafleat terhadap kepatuhan ibu hamil mengkonsumsi tablet besi. Jurnalelektronik Volume VI Nomor 3

Hardi Prasetiawan (2017), Optimalisasi dalam layanan bimbingan dan konseling. Prosiding Seminar Bimbingan dan Konseling Tersedia Online di Vol. 1, No. 1, 2017, hlm. 199-204 